\title{
L'enfer, c'est les autres
}

Le lac.

Sur un bateau, plusieurs pêcheurs attendent.

Longue patience.

Soudain: "Poissons à tribord!»

Tous les pêcheurs se précipitent à tribord.

Et le bateau chavire.

Moralité: s'entendre et coopérer plutôt que sombrer.

A moins de vouloir jouir de cette pensée masochiste et destructrice: "nous avons coulé, oui, mais c'est à cause des autres!"

Dr Claude Aubert, membre du CC de la FMH 